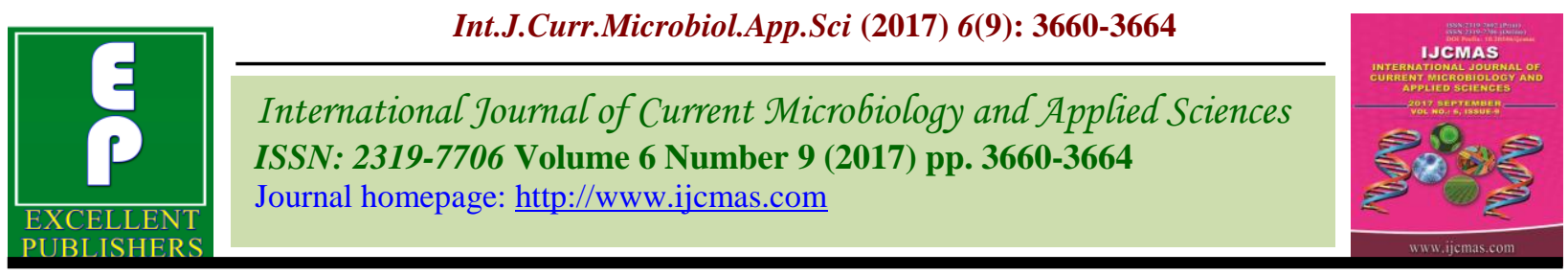

Review Article

https://doi.org/10.20546/ijcmas.2017.609.450

\title{
Strategies for Effective Transfer of Climate Resilient Agriculture (CRA) Technologies
}

\author{
T. Archana ${ }^{1 *}$, V. Sudha Rani ${ }^{1}$, K. Nagasree ${ }^{2}$ and K.B. Suneetha Devi ${ }^{3}$ \\ ${ }^{1}$ Department of Agriculture Extension, College of Agriculture, PJTSAU Rajendrangar, \\ Hyderabad.500030, Telangana, India \\ ${ }^{2}$ Dept. of Agriculture Extension, CRIDA, Santhosh Nagar, Hyderabad.500030, Telangana, India \\ ${ }^{3}$ Department of agronomy, College of Agriculture, PJTSAU Rajendrangar, Hyderabad.500030, \\ Telangana, India \\ *Corresponding author
}

A B S T R A C T

\begin{tabular}{|c|c|}
\hline & \multirow{4}{*}{$\begin{array}{l}\text { For effective transfer of Climate Resilient Agriculture (CRA) technologies the } \\
\text { Government }(\mathrm{G}) \text {, extension }(\mathrm{E}) \text { and research }(\mathrm{R}) \text { system should work co-operatively } \\
\text { with Truth }(\mathrm{T}) \text { and equal justice }(\mathrm{J}) \text { and without bias and political interference for the } \\
\text { farmers }(\mathrm{F}) \text {. These three }(\mathrm{G}, \mathrm{E} \& \mathrm{R}) \text { bodies should communicate, serve the farmers } \\
\text { continuously and take feedback from the farmers, this action }(\mathrm{A}) \text { and reactions }(\mathrm{R}) \\
\text { should be continuous }(\mathrm{C}) \text { then only the farmer may trust }(\mathrm{T}) \text { the government, } \\
\text { extension and research system and the farmers show the interest to adopt the } \\
\text { Climate Resilient Agriculture (CRA) technologies. }\end{array}$} \\
\hline $\begin{array}{l}\text { Climate Resilient } \\
\text { Agriculture (CRA) } \\
\text { technologies. }\end{array}$ & \\
\hline Article Info & \\
\hline $\begin{array}{l}\text { Accepted: } \\
\text { 10 July } 2017 \\
\text { Available Online: } \\
10 \text { October } 2017\end{array}$ & \\
\hline
\end{tabular}

\section{Introduction}

At present India's geographical area under agriculture is about 46 per cent. A large percentage of this land falls in rain-fed regions generating 55 percent of the country's agricultural output, providing food to 40 percent of the nation's population (Planning Commission, 2012). More than 80 per cent of the farmers are small holder producers, with very poor capacity and resources to deal with the vagaries of weather and changes in climate. Current trends estimate that 60 percent of India's ground water sources will be in a critical state of degradation within the next twenty years (World Bank, 2010).
According to the IPCC, in the changing climate scenario, the demand for irrigation in arid and semi-arid regions of Asia is estimated to increase by at least 10 percent for an increase in temperature by $1{ }^{\circ} \mathrm{C}$ (Bates et al., 2008). About 60 per cent of our Indian agriculture is being rain fed. Monsoons plays very important role in agriculture. If the failure in the monsoons, the drought will occur due to low rainfed crops yield. It leads to poor socio economic status of the small and medium farmers. For the changing climate, farmers should adopt appropriate climate resilient agriculture technologies and coping 
mechanisms to overcome the climate vagaries. Due to some of the problems the CRA technologies and coping mechanisms are not reaching properly to the door step of farmers. Hence there is a need to transfer technologies for CRA.

\section{Strategies for extension (E)}

More number of trainings, demonstrations, meetings and other extension activities should be taken up in the village only. This can be achieved by maintaining one village school in one central village for every selected five villages (V5 School) to reach to every farmer, through implementation of extension activities.

Interested youth had to be identified and give them skill training and provide tabs, agricultural kit, knowledge product and also give them training on how to use the mass media like mobile apps down loading related to weather, marketing, pest and disease diagnosis. And also give trainings on computers with internet facilities to search the agriculture web portals and how to interact with scientist by asking queries. One information kiosk/V5 school or one ICT initiative/V5 school with interactive portal to communicate with scientist for further queries in V5 School (for five villages) along with one farm care manager, crop doctor and AEO for regular field visits and to solve the farmer's problems. The farm care manager should take care of the all farmers needs. The ICT initiative will give the information to farmers of five villages regarding CRA technologies.

Computer with one computer operator should be necessary at V5school. In this computer village action plan (VAP) should be placed based on survey of farm holding, existing farming practices, farm size, soil health cards, socio economic status of farmers, availability of water and farm power etc. These all farmers details of five villages should be linked to the projects and developmental programmes which are running in the villages and also link this information to the PACS, cooperative banks/commercial banks and Pradhan Mantri Fasal Bima Yojana (PMFBY), NABARD and reserve bank for facilitating web based monitoring and evaluation of implementation of schemes related to crop insurance, crop loans and subsidies by providing them RUPEE card.

Documented valued ITKs should be provided in the V5 school computers and share to the farmers of other villages.

\section{Strategies for research}

Research should be in participatory mode to validate climate prediction of ITKs blended with WBAAS and may be diffused through farmer to farmer extension.

Research should be location specific and need-based research.

Farmer's decision should be preferred prior to research development which ensures Participatory research development.

Activities to be taken up for Documentation and validation of ITKs

\section{Strategies for farmers}

Farmers have to use a local contingency plans to cover new and evolving risk scenario due to climate change.

Farmer should share the ITKs of CRA to the officials.

Farmers have to get empowered and should form associations for different crops and fix the MSP for their produce with the help of Government and store their farm produce in godowns 
Strategies for transfer of technologies for Climate Resilient Agriculture (CRA)

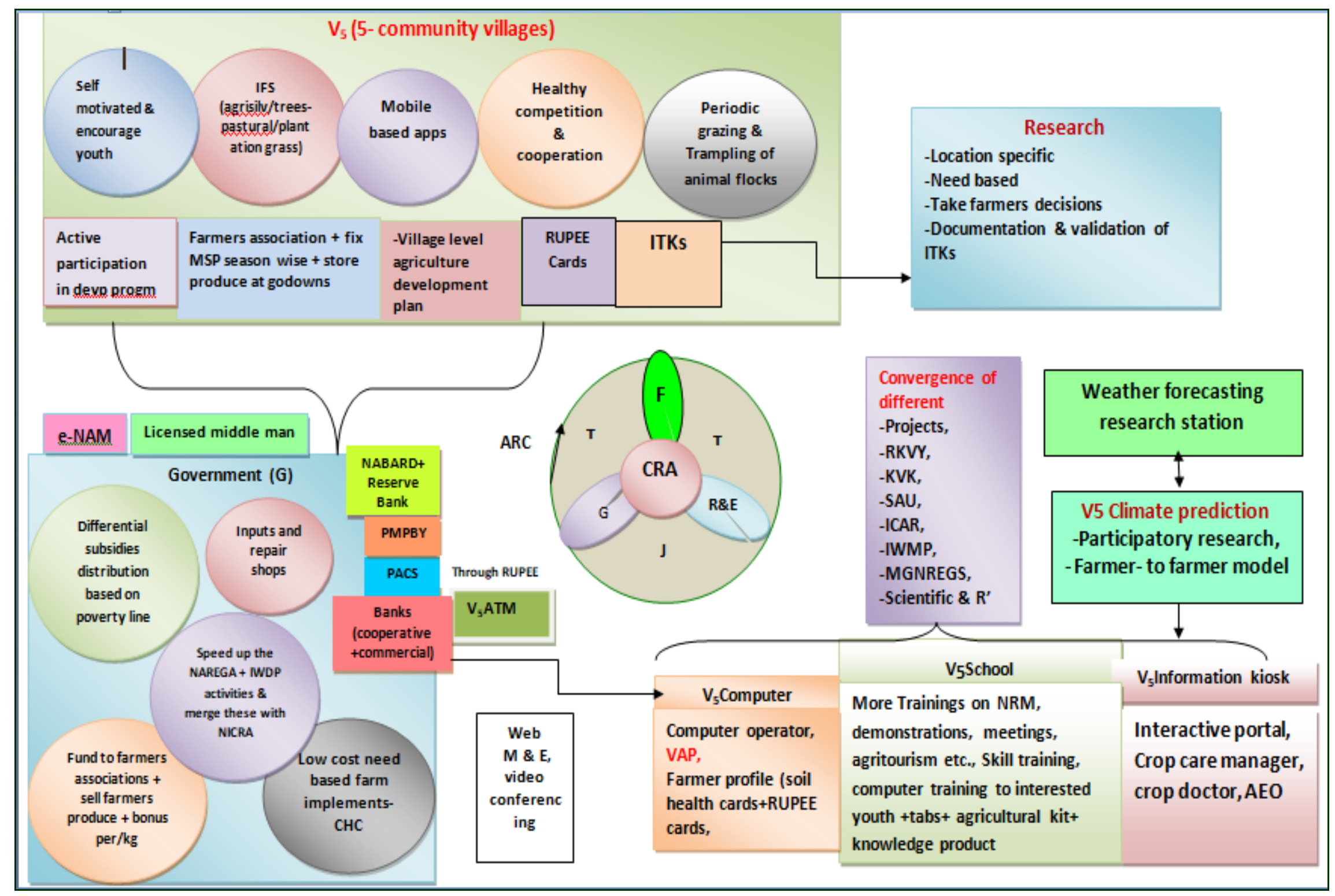


These farmer groups should use the social media to share the information to other farmers and these farmers should use mobile apps related to agriculture

After cash crops farmers should grow catch crops and alternate rows with erosion resisting cover crops for better absorption of nutrients from the soil. (e.g. Ground nut + red gram followed by pear millet, cover crops like green gram, horse gram etc.)

Farmers should follow Integrated farming systems (agrisilvi/tree pastural/plantation grass) and periodic trampling of animal flocks to reduce the over grazing and to decay grass biologically. Through this farmer can minimise the overheat which is generated by sheep penning activity due to poor moisture availability in the soils to decompose manure.

\section{Strategies for Government}

One Cooperative bank with one ATM facility and one primary agriculture cooperative society for five villages for easy access of subsidized inputs and crop loans and crop insurance to the farmers by providing them RUPEE cum ATM card

Government, NGOs and voluntary organizations should work together for providing new farm machinery, management and operation of $\mathrm{CHC}$ in NICRA villages to reduce the drudgery of the farmers when there is labour scarcity for land preparation to harvesting of crop.

A number of central/state government projects/schemes on water and soil conservation are running parallel to NICRA. Efforts should be made to converge these schemes with NICRA so as to obtain synergic impact.

Government micro irrigation project should be converged with NHM, SHM (national and state horticulture mission) for efficient utilization of stored rainwater of farm ponds with micro irrigation.

Speed up the NAREGA and IWMP activities and merge these programmes with the NICRA for reducing the repetition and time for the NRM practices.

In Nalgonda district of Telangana MGNREGA and Mission Kakatiya programmes of GOI can be converged for excavation of ponds and applying tank silt in light textured soils to provide higher moisture retention and improves the soil fertility.

Inputs, repair shops related to agriculture implements and veterinary dispensary and other important resources should be provided by the Government.

Provide sufficient fund to registered farmers associations of drought prone areas.

Government has to bear the burden of marketing of farmers produce by colleting the produce from the godowns of farmers associations because most of the farmers are getting low yields from the rainfed crops and also they are exploited middle men. Government should create online marketing facility through licensed middle man by fixing the minimum support price. Then only the farmer may economically combat to drought and come forward to adopt more CRA technologies.

In adopted villages de silting of defunct check dams and water harvesting structures are not in time as it is capital and labour intensive thus, can be converged with RKVY, MGNREGA, NHM and IWMP programmes of GOI.

Empower the farmers by providing financial support to strengthen functioning of custom hiring centers, fodder bank, seed bank and 
VCRMC and motivate them by granting incentives for best performers.

Farmers were facing problem to store farm equipments and machineries due to inadequate building facilities. Thus the need is for construction and renovation of building for CHCA godown and drying platform should be constructed for every five village.

For the changing climate, farmers should adopt appropriate climate resilient agriculture technologies and coping mechanisms to overcome the climate vagaries. Due to some of the problems the CRA technologies and coping mechanisms are not reaching properly to the door step of farmers. Effective transfer of CRA technologies can only possible by providing good strategies to government, extension and research system and farmers.

\section{References}

Bates, B.C., Z.W. Kundzewicz, S. Wu, and J.P. Palutikof (Eds.), 2008. Climate Change and Water. Technical Paper of the Intergovernmental Panel on Climate Change, IPCC Secretariat, Geneva, pp 210. Available at www.ipcc.ch/pdf/technicalpapers/climat e-change-water-en.pdf. Accessed 3 January 2012.

David Pimentel, 1995. Amounts of pesticides reaching target pests: Environmental impacts and ethics. Journal of Agricultural and Environmental Ethics. 8 (1): 17-29.

Dipak Zade, K., Bhavana Rao, Ramkumar Bendapudi and Marcella D'souza 2013.
Towards Resilient Agriculture in a Changing Climate Scenario. Published by: Watershed Organisation Trust (WOTR), Pune.

Iqbal Singh, and Jagdish Grover 2013. Role of extension agencies in climate change related adaptation strategies. International Journal of Farm Sciences 3(1): 144-155.

Noorjehan A.K.A., Hanif and Mohammed Iqbal 2012. Extension Strategies to Promote Non-Polluting Environment in Fruit Eco System for Sustainable Agriculture Indian Res. J. Ext. Edu. 12 (3) 53.

Planning Commission, 2012. Report of working group on warehousing development and regulation for the twelfth plan period. Planning Commission, New Delhi. Available at http://planningcommission.gov.in/ aboutus/committee/wrkgrp12/pp/wg_ ware.pdf.

Shaik, N., Balaji V, Muthuraman P, Sailaja B and Dixit S 2011. Changing Roles of Agricultural Extension: Harnessing Information and Communication Technology (ICT) for Adapting to Stresses Envisaged Under Climate Change.

Venkateswarlu, B., Shanker A.K., Shanker C and Maheswari M. Crop Stress and its Management: Perspectives and Strategies (pp585-605).

World Bank. 2010. Deep wells and prudence: Towards a pragmatic action for addressing ground water over exploitation in India'. World Bank.

\section{How to cite this article:}

Archana, T., V. Sudha Rani, K. Nagasree and Suneetha Devi, K.B. 2017. Strategies for Effective Transfer of Climate Resilient Agriculture (CRA) Technologies. Int.J.Curr.Microbiol.App.Sci. 6(9): 3660-3664. doi: https://doi.org/10.20546/ijcmas.2017.609.450 